\title{
Importance of mastalgia in operable breast cancer
}

\author{
P E PREECE, M BAUM, R E MANSEL, D J T WEBSTER, R W FORTT, I H GRAVELLE, \\ L E HUGHES
}

\begin{abstract}
The importance of pain as a presenting symptom of breast cancer has been assessed in a series of 240 patients with operable breast cancer over four years. From an analysis of the case histories of 36 patients the diagnosis proved difficult in one-quarter of the cancers. This is explained by the high incidence of subclinical and lobular carcinoma in the group. Cancer must be seriously considered as a diagnosis in patients presenting with welllocalised breast pain of recent onset. These patients should be followed for at least one year after the onset of the pain before cancer is confidently excluded.
\end{abstract}

\section{Introduction}

At present pain tends to be disregarded in the diagnosis of breast cancer. In fact, it is often said that the presence of pain excludes this diagnosis; the reasons given are its reported infrequency in operable disease, ${ }^{1}$ its variability, ${ }^{2}$ and the common occurrence of the symptom in benign breast disease. ${ }^{3}$ Our finding that onethird of patients with subclinical breast cancers presented with pain ${ }^{4}$ has prompted a review of early breast cancers in which pain was a presenting symptom.

\section{Patients and methods}

At their first visit to the breast clinic in Cardiff all patients complete a questionnaire, which aims at systematic and complete collection of relevant information. Pain in the breast is included in the list of symptoms. Patients who have no clinical or radiological evidence suggesting cancer, and whose pain is resistant to reassurance and simple therapeutic measures, are then referred to a special mastalgia clinic for a more detailed history and investigation of their breast pain.

Over four years, during which about 240 new cases of operable breast cancer were seen, 36 patients ( 34 with invasive and two with intraduct carcinoma) had breast pain as one of their presenting symptoms. Thirty-three of these patients were recognised as having cancer at the initial diagnostic investigation and were treated in the primary breast clinic. The diagnosis was missed on initial investigation in the remaining three patients, who were referred to the mastalgia clinic. During the same four years, 500 patients with persistent mastalgia were referred to the mastalgia clinic.

All except two of the 36 patients had bilateral mammography performed in two planes. Where a palpable mass was present, biopsy was performed either by Tru-cut (Travenol Laboratories) needle ${ }^{5}$ or

University Departments of Surgery and Pathology, Welsh National School of Medicine, Cardiff CF4 4XN

P E PREECE, FRCS, senior lecturer and honorary consultant surgeon (present appointment: Department of Surgery, Ninewells Hospital, Dundee DD1 9SY)

M BAUM, CHM, FRCS, professor (present address: Department of Surgery, King's College Hospital Medical School, London SE5 8RX)

$R$ E MANSEL, FRCS, senior lecturer and honorary consultant surgeon

D J T WEBSTER, FRCS, senior lecturer and honorary consultant surgeon

R W FORTT, FRCPATH, senior lecturer and consultant pathologist

L E HUGHES, DSC, FRCS, FRACS, professor of surgery

Department of Diagnostic Radiology, University Hospital of Wales, Cardiff

I H GRAVELLE, FRCPE, FRCR, consultant radiologist by excision. When malignancy was suspected radiologically in the absence of a clinical lesion tissue diagnosis was made by a double-dye localising technique. ${ }^{4}$

\section{Results}

The mean age of the 36 patients was 48 years, range 31-77 years. Twenty-two patients were premenopausal. Pain was the sole presenting symptom in $17\left(47^{\circ}\right)$, whose mean age was 45 years and of whom eight were premenopausal. The commonest associated symptom was a mass noticed by the patient. In all patients the site of the pain corresponded to the site of the cancer.

Table I shows the TNM stages ( $T$, tumour size; $N$, state of regional lymph nodes; $M$, presence or absence of distant metastases) of the patients subdivided into those with pain as their sole presenting symptom and those who had additional complaints. Pain was the sole symptom in all five subclinical $\left(T_{0}\right)$ lesions. Of the nine $T_{1}$ tumours, pain was the sole presenting symptom in five $(56 \%)$, as in only seven $(31 \%)$ of the $22 \mathrm{~T}_{2}$ tumours. The degree of axillary node involvement by histopathology is shown in table II, with the cases subdivided as in table I. Because of the use of simple mastectomy and random node biopsy during the earlier part of this series, node histology was not available in some of the earlier patients. Table III shows the histopathology of the primary cancers; six cases were of lobular carcinoma and two with pain only were in-situ ductal carcinomas.

The distribution of radiological signs of malignancy for each histo-

\begin{tabular}{|c|c|c|c|}
\hline $\begin{array}{c}\text { TNM stage } \\
\text { at presentation }\end{array}$ & Pain only & $\begin{array}{c}\text { Pain and } \\
\text { other symptoms }\end{array}$ & No \\
\hline 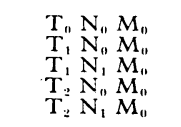 & $\begin{array}{l}5 \\
2 \\
3 \\
5 \\
2\end{array}$ & $\begin{array}{r}0 \\
3 \\
1 \\
3 \\
12\end{array}$ & $\begin{array}{r}5 \\
5 \\
4 \\
8 \\
14\end{array}$ \\
\hline Total & 17 & 19 & 36 \\
\hline
\end{tabular}

TABLE II-Histopathology of axillary nodes in 36 women with breast cancer and mastalgia

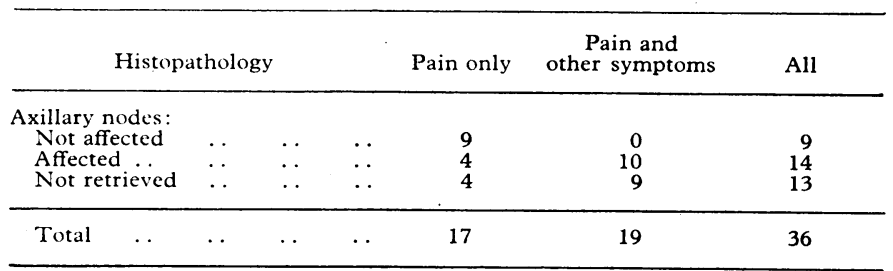

TABLE III-Histopathology of the primary tumours in 36 women with breast cancer and mastalgia

\begin{tabular}{|c|c|c|c|c|c|c|}
\hline \multicolumn{4}{|c|}{ Primary tumour } & \multirow{2}{*}{$\begin{array}{r}\text { Pain } \\
4 \\
2 \\
11\end{array}$} & \multirow{2}{*}{$\begin{array}{c}\begin{array}{c}\text { Pain and } \\
\text { other symptoms }\end{array} \\
2 \\
0 \\
17\end{array}$} & \multirow{2}{*}{$\begin{array}{r}\text { All } \\
6 \\
2 \\
28\end{array}$} \\
\hline $\begin{array}{l}\text { Invasive lobular } \\
\text { In-situ ductal } \\
\text { Invasive ductal }\end{array}$ & $\begin{array}{l}\ldots \\
\cdots\end{array}$ & $\begin{array}{l}\cdots \\
\cdots \\
\cdots\end{array}$ & $\begin{array}{l}\ldots \\
\cdots\end{array}$ & & & \\
\hline Total & . & .. & . & 17 & 19 & 36 \\
\hline
\end{tabular}


pathological group is shown in table IV. More than one sign was present in some cases. In 10 patients cancer was not recognised as such on initial mammography. Three were cases of subclinical lobular carcinoma. One had a vague architectural deformity, only recognised in retrospect five months later when it became more pronounced on follow-up radiographs. Of two patients who had no radiological signs of malignancy, one developed a palpable nodule which underwent biopsy nine months after presentation, and one underwent biopsy because the vague thickening palpated at first visit persisted. Seven invasive ductal cancers were not diagnosed by radiography; one had a mass interpreted as periductal mastitis and two had incidental benign calcifications. In the one patient who had no clinical or radiological signs on presentation, a discrete mass was palpated four months later at the site of the presenting complaint of continuous pain.

To date, the mean follow-up time of patients in this series is 7.5 years, ranging from 5 to 10 with a median of eight years. Table $\mathrm{V}$ shows the outcome so far for each TNM stage at presentation.

TABLE IV-Mammographic signs of breast cancer in 36 women with breast cancer and mastalgia

\begin{tabular}{|c|c|c|c|c|}
\hline & & Lobular & $\begin{array}{l}\text { In-situ } \\
\text { ductal }\end{array}$ & $\begin{array}{c}\text { Invasive } \\
\text { ductal }\end{array}$ \\
\hline $\begin{array}{l}\text { Mass/increased density } \\
\text { Microcalcification } \\
\text { Architectural disturbance } \\
\text { Hypervascularity } \\
\text { Skin thickening }\end{array}$ & $\begin{array}{l}\ldots \\
\cdots \\
\cdots \\
\cdots\end{array}$ & $\begin{array}{l}2 \\
0 \\
1 \\
0 \\
0\end{array}$ & $\begin{array}{l}0 \\
2 \\
1 \\
1 \\
0\end{array}$ & $\begin{array}{r}23 \\
7 \\
0 \\
4 \\
1\end{array}$ \\
\hline
\end{tabular}

TABLE $\mathrm{v}-D e a t h s$ and recurrences at $7 \frac{1}{2}$ years in 36 women with breast cancer and mastalgia

\begin{tabular}{ccccc}
\hline $\begin{array}{c}\text { TNM stage } \\
\text { at presentation }\end{array}$ & No & Died & $\begin{array}{c}\text { Alive/ } \\
\text { recurred }\end{array}$ & $\begin{array}{c}\text { Alive/ } \\
\text { no recurrence }\end{array}$ \\
\hline $\mathrm{T}_{0} \mathrm{~N}_{0} \mathrm{M}_{0}$ & 5 & 0 & 0 & 5 \\
$\mathrm{~T}_{1} \mathrm{~N}_{0} \mathrm{M}_{0}$ & 5 & 0 & 0 & 5 \\
$\mathrm{~T}_{1} \mathrm{~N}_{1} \mathrm{M}_{0}$ & 4 & 1 & 1 & 2 \\
$\mathrm{~T}_{2} \mathrm{~N}_{0} \mathrm{M}_{0}$ & 8 & 2 & 1 & 5 \\
$\mathrm{~T}_{2} \mathrm{~N}_{1} \mathrm{M}_{0}$ & 14 & 8 & 3 & 3 \\
\hline Total & 36 & 11 & 5 & 20 \\
\hline
\end{tabular}

\section{Discussion}

Pain is the commonest breast symptom. ${ }^{6}$ Usually it reflects normal physiological processes or benign breast disease. The present series shows that this is not always a safe assumption, as has been shown ${ }^{7}$ (although often ignored) in previous series. The incidence of pain as the presenting symptom in such series ranges between $5 \%$ and $17 \%,{ }^{6-10}$ figures comparable to our finding that $15 \%$ of cases of operable breast cancer have pain as one of their presenting complaints, and $7 \%$ complain of mastalgia alone. This series also confirms that pain in breast cancer can lead to early diagnosis. ${ }^{11}{ }^{12}$ This is particularly true for those patients presenting with pain alone, in whom onethird of cancers are subclinical-that is, they are not detectable by palpation (table I). By coincidence, one-third of subclinical cancers present with pain. ${ }^{4}$ For the whole series $25 \%$ of painful operable cancers are $\mathrm{T}_{1} \mathrm{~N}_{0} \mathrm{M}_{0}$ and $15 \%$ subclinical.

We have been unable to correlate any descriptive terms used by patients for their pain with any definable features of the tumours. ${ }^{2}$ Unlike Corry, however, we have found that some patients volunteered the information that the pain radiated to the axilla or arm, a common feature of pain in benign breast disease. Contrary to previous teaching, therefore, axillary radiation cannot be assumed to exclude malignancy. Despite this radiation outside the breast, the pain within the breast tends to be well localised and persistent.

About half the patients studied, both those with mastalgia as their only complaint and the group as a whole, were premenopausal at the time of presentation. This has the important implication that mastalgia can be a sign of malignancy in premenopausal as in postmenopausal women. Similarly, since breast pain is so much less common after the menopause, its development at this time must be given particular attention.

The false-negative rate by mammography in Cardiff is $8-10 \%$. Among the 36 patients studied, $25 \%$ of malignancies were not recognised on the initial mammogram; one-third of these were not even suspected clinically. Half the lobular cancers were not detected mammographically; this neoplasm is well known for eluding radiologists. ${ }^{13} 14$ With the other tumours there was a particular low incidence of microcalcification, which undoubtedly played an important part in the low diagnostic rate. We have no explanation for it, apart from the high incidence of very early tumours.

Six $(16 \%)$ cases of lobular carcinoma, in 36 breast cancers, is a high proportion. In the Cardiff mastectomy trial ${ }^{15}$ the local incidence was about $2 \cdot 5 \%$ of all stage I and II breast cancers. This suggests that lobular carcinoma in particular causes pain, which is important because of the difficulty of radiological diagnosis $^{13}$ and histological diagnosis by frozen section histology, ${ }^{16}$ particularly when the cancer is preinvasive. Because of these difficulties women who present with mastalgia, especially over the age of 30 years,,$^{17} 18$ should be investigated at least as thoroughly as if they complained of a lump or a nipple discharge. If localised pain persists after negative investigation, assessment should be repeated for at least 12 months.

In the present study the figures were too small and the followup period too short for accurate analysis. The results stage for stage probably do not differ from wider series. They do strongly suggest, however, that if attention is paid to breast pain a high proportion of early tumours are diagnosed. In this way the advantages of earlier presentation can be exploited.

This study was supported by a grant from the Medical Research Council.

\section{References}

${ }^{1}$ Haagensen CD. Diseases of the breast, 2nd ed. Philadelphia: W B Saunders, $1971: 467$.

2 Corry DC. Pain in carcinoma of the breast. Lancet 1952 ;ii :274-6.

${ }^{3}$ River L, Silverstein J, Grout J, et al. Carcinoma of the breast: the diagnostic significance of pain. Am $\mathcal{F}$ Surg 1951;82:733-5.

4 Preece PE, Gravelle IH, Hughes LE, Baum M, Fortt RW, Leopold JG. Operative management of subclinical breast cancer. Clin Oncol 1977;3 : 165-9.

5 Roberts JG, Preece PE, Bolton PM, Baum M, Hughes LE. The "tru-cut" biopsy in breast cancer. Clin Oncol 1975;1:297-304.

${ }^{6}$ Haagensen CD. Diseases of the breast. 2nd ed. Philadelphia: W B Saunders, $1971: 101$.

${ }^{7}$ Lane-Claypon Janet E. A further report on cancer of the breast with special reference to its associated antecedent conditions. Reports on Public Health and Medical Subjects 1926;32:1-189.

${ }^{8}$ Luff AP. The incidence of cancer of the breast and its history after treatment. Br Med F 1923;i:897-903.

9 Cade S. Malignant disease and its treatment by radium. Bristol: John Wright and Sons, 1940:753.

${ }^{10}$ Geschickter CF. Diseases of the breast. 2nd edn. London: J B Lippincott and Co, $1945: 445$.

11 Truscott BM. Carcinoma of the breast. An analysis of the symptoms, factors affecting prognosis, results of treatment and recurrences in 1211 cases. Br f Cancer 1947;1:129-45.

12 Aubert U, Moiroud P. Valeur de la douleur comme signe de debut du cancer du sein. Bulletin et Memoires de la Société Anatomique de Paris $1922 ; 92: 270-2$.

13 Snyder RE. Mammography and lobular carcinoma in situ. Surg Gynecol Obstet 1966;122:255-60.

14 Evans KT, Gravelle IH. Mammography, thermography and ultrasonography in breast diseases. London: Butterworth Press, 1973:52.

15 Forrest APM, Roberts MM, Preece PE, et al. The Cardiff St Mary's trial. Br f Surg 1974;61:766-9.

${ }^{16}$ Farrow JH. Clinical considerations and treatment of in situ lobular breast cancer. Am F Roentgenol 1968;102:652-6.

17 Ashikari R, Huvos AG, Urban JA, Robbins GF. Infiltrating lobular carcinoma of the breast. Cancer 1973;31:110-6.

(Accepted 18 March 1982) 